\title{
Primary Extranodal Non-Hodgkin Lymphomas: A First Tertiary Care Experience from Punjab, North India
} \author{
Kunal Jain ${ }^{2}$ Sumit Grover ${ }^{1}$ \\ ${ }^{1}$ Department of Pathology, Dayanand Medical College and Hospital, \\ Ludhiana, Punjab, India \\ ${ }^{2}$ Department of Medical Oncology, Dayanand Medical College and \\ Hospital, Ludhiana, Punjab, India
}

Vikram Narang ${ }^{1} \quad$ Steffi ${ }^{1} \quad$ Aminder Singh ${ }^{1} \quad$ Neena Sood ${ }^{1} \quad$ Bhavna Garg ${ }^{1}$ Harpreet Kaur ${ }^{1}$

\begin{abstract}
Address for correspondence Dr Kunal Jain, MD DNB, MNAMS, Assistant Professor Department of Medical Oncology AOI, Dayanand Medical College and Hospital, Ludhiana, Punjab, India (e-mails: drvikramnarang@yahoo.com; drkunaljain1@gmail.com).
\end{abstract}

South Asian J Cancer 2021;9:230-232.

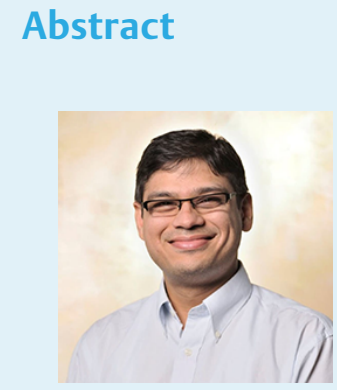

Dr Kunal Jain
Keywords

- extranodal

- India

- lymphomas
Background Primary extranodal lymphomas are less frequently encountered and difficult to diagnose in routine practice. The histopathological and immunohistochemical studies are essential in addition to clinical details to diagnose. The incidence is varied in different parts of India along with variation in histopathological spectrum.

Methodology The clinical features and histopathological findings of patients diagnosed with primary extranodal lymphoma over 3-year period were retrieved from archives of pathology department and analyzed.

Results During the 3-year study period, a total of 135 cases of non-Hodgkin lymphomas were evaluated, and of these, $41.4 \%$ (56/135) of cases presented with primary extranodal involvement. The mean age of primary extranodal lymphoma presentation was $61.3 \pm 17.5$ with $\mathrm{M}: \mathrm{F}$ ratio of 1:1.1 Most common extranodal site involved was gastrointestinal tract $32.1 \%, 18 / 56$ (small intestine [17.8\%, 10 cases] and large intestine $[8.9 \%, 5$ cases]). Non-Hodgkin lymphomas of B cell type were the predominant subtype $(48 / 56,85.7 \%)$, while $8 / 56$ (14.2\%) cases were of T cell lineage. Of the B cell non-Hodgkin lymphoma diffuse, large B cell lymphoma was the predominant subtype constituting $~ 83.3 \%$ (40/48).

Conclusion Primary extranodal lymphomas exhibit varied histomorphological and clinical presentation. The present study is first such analysis from Punjab that intends to compare with studies from other parts of India.

\section{Introduction}

Primary extranodal lymphoma (pENL) constitutes $\sim 25 \%$ of all non-Hodgkin lymphoma (NHL) and refers to group of disorders arising from tissues other than lymph nodes. pENL is a frequent diagnostic challenge to the clinicians and pathologists due to their varied clinical presentations, histomorphological mimicry, and molecular alterations. The incidence of pENL is increasing and is attributed primarily to improved knowledge in diagnostic immunophenotyping and imaging modalities. The common sites involved include the central nervous system, the gastrointestinal tract (GIT), and the skin..$^{1-3}$ This site-specific incidence might be attributed to environmental factors, chronic infections, immunosuppressive, and autoimmune disorders. Although there are many case reports and series dealing with extranodal lymphoma of the various sites of the body, the literature from North India, especially Punjab on pENL, is limited.
DOI https://doi.org/10.1055/s-0041-1723073 ISSN 2278-330X.

How to cite this article: Narang V, Steffi, Singh A, Sood N, Garg B, Kaur H, Jain K, Grover S. Primary Extranodal Non-Hodgkin Lymphomas: A First Tertiary Care Experience from Punjab, North India. South Asian J Cancer 2021;9(4):230-232. (c) 2021. MedIntel Services Pvt Ltd.

This is an open access article published by Thieme under the terms of the Creative Commons Attribution-NonDerivative-NonCommercial-License, permitting copying and reproduction so long as the original work is given appropriate credit. Contents may not be used for commercial purposes, or adapted, remixed, transformed or built upon. (https://creativecommons.org/licenses/by-nc-nd/4.0/)

Thieme Medical and Scientific Publishers Pvt. Ltd., A-12, 2nd Floor, Sector 2, Noida-201301 UP, India 


\section{Methodology}

\section{Study Design}

The present 3-year retrospective study was conducted in the Department of Pathology, Dayanand Medical College and Hospital, Ludhiana, Punjab. The demographic and clinical features, laboratory parameters, imaging findings, histopathology, and immunophenotyping of all the patients presenting with pENL were documented, and descriptive analysis was done.

\section{Case Selection}

All patients who present with NHL that apparently originated at an extranodal site, even in the presence of disseminated disease, as long as the extranodal component, was clinically dominant were defined as extranodal lymphomas. Patients presenting with symptoms of lymphadenopathy and other systemic organ involvement were examined. Biopsy and excision specimens were fixed in formalin ( $10 \%$ solution of formaldehyde in buffered alcohol) and then processed and stained with hematoxylin and eosin stain. Immunohistochemistry was done in all cases for further typing and classification.

The study was approved by the institutional ethic committee (vide letter number BFUHS/2K17p-TH/11162), and appropriate consent of patients were taken.

\section{Results}

During the 3-year study period, a total of 135 cases of NHL were evaluated, and of these, $41.4 \%$ (56/135) of cases presented with primary extranodal involvement. The mean age of pENL presentation was $61.3 \pm 17.5$ with M:F ratio of $1: 1.1$. Organomegaly and $\mathrm{B}$ symptoms were noted in 28.5\% (16/56) patients. Most common extranodal site involved was GIT 32.1\%, 18/56 (small intestine [17.8\%, 10 cases], large intestine [8.9\%, 5 cases], and stomach [5.3\%, 3 cases]) followed by thyroid $(10.7 \%, 6$ cases), brain $(8.9 \%$, 5 cases), liver (8.9\%, 5 cases), spleen (5.3\%, 3 cases), breast (3.5\%, 2 cases), lung (3.5\%, 2 cases), pancreas (3.5\%, 2 cases), parotid (3.5\%, 2 cases), tonsils (3.5\%, 2 cases), and a single case $(1.8 \%)$ each involving the followings sites such as chest wall, frontal sinus, kidney, bone, nasopharyngeal mass, rectal biopsy, scapula, skin, stomach, temporozygomatic mass, and testis.

NHL of B cell type were the predominant subtype (48/56, 85.7\%), while 8/56 (14.2\%) cases were of T cell lineage. Of the B cell NHL diffuse, large B cell lymphoma was the predominant subtype constituting $\sim 83.3 \%$ (40/48), followed by marginal zone lymphoma, follicular lymphoma, and Burkitt lymphoma each constituting $\sim 4.16 \%$ (2 cases each), precursor B-lymphoblastic lymphoma and chronic lymphocytic leukemia/small lymphocytic leukemia each constituting $2.13 \%$ ( 1 case each). Of the T cell lymphomas, peripheral $\mathrm{T}$ cell lymphoma not otherwise specified (NOS) $50 \%$ (4 cases) and precursor T-lymphoblastic lymphomas $22.2 \%$ ( 2 cases) were recovered followed by anaplastic largecell lymphoma and cutaneous T cell lymphoma $11.1 \%$ (1 case each) (- Table 1 ).
Table 1 Histomorphological and immunophenotypic subtypes if primary extranodal lymphoma

\begin{tabular}{|l|l|l|}
\hline $\begin{array}{l}\text { Histomorphological } \\
\text { and } \\
\text { immunophenotypic } \\
\text { subtypes }\end{array}$ & Site & $\begin{array}{l}\text { Number } \\
\text { of cases } \\
\text { (N = 56), } \\
n(\%)\end{array}$ \\
\hline $\begin{array}{l}\text { Diffuse large B cell } \\
\text { lymphoma }\end{array}$ & $\begin{array}{l}\text { Gl, breast, kidney, lung, } \\
\text { testis, spleen }\end{array}$ & $40(71.4)$ \\
\hline $\begin{array}{l}\text { Marginal zone } \\
\text { lymphoma }\end{array}$ & Parotid & $2(3.5)$ \\
\hline Follicular lymphoma & Bone, chest wall & $2(3.5)$ \\
\hline $\begin{array}{l}\text { Burkitt lymphoma } \\
\text { small intestine }\end{array}$ & $2(3.5)$ \\
\hline $\begin{array}{l}\text { Precursor } \\
\text { B-lymphoblastic } \\
\text { lymphoma }\end{array}$ & Liver & $1(1.7)$ \\
\hline $\begin{array}{l}\text { Small lymphocytic } \\
\text { lymphoma }\end{array}$ & Liver & $1(1.7)$ \\
\hline $\begin{array}{l}\text { Peripheral T cell } \\
\text { lymphoma NOS }\end{array}$ & Small intestine, liver & $4(7.0)$ \\
\hline $\begin{array}{l}\text { Precursor } \\
\text { T-lymphoblastic } \\
\text { lymphoma }\end{array}$ & Thyroid, liver & $2(3.5)$ \\
\hline $\begin{array}{l}\text { Anaplastic large cell } \\
\text { lymphoma }\end{array}$ & Small intestine & $1(1.7)$ \\
\hline $\begin{array}{l}\text { Cutaneous T cell } \\
\text { lymphoma }\end{array}$ & Skin & $1(1.7)$ \\
\hline Abrevions: & Largestine, \\
\hline
\end{tabular}

Abbreviations: Gl, gastrointestinal; NOS, not otherwise specified.

\section{Discussion}

pENLs are a heterogeneous group of tumors because of its difference in epidemiology and etiology in different areas around the world. The present 3-year study is the first experience from Punjab, North India, focusing on pENL. The most common site involved was GIT $(18 / 56,32.1 \%)$, of which small intestine $(10 / 18,55.5 \%)$ was the frequently involved. Diffuse large B cell lymphoma was the most common histological subtype of all the B cell NHL (40/48, 83.3\%) that were further subclassified into germinal center subtype (19/40, 47.5\%) and nongerminal center subtype based on Hans Classifier (CD 10, BCL6, and MUM 1)., ${ }^{4,5}$ Gogia et al also reported diffuse large B-cell lymphoma being the most common subtype with extranodal involvement in $34.8 \%$ patients. Fifty patients had pENL with stomach and intestine being the most common site followed by central nervous system. The information regarding cell of origin (based of Hans algorithm) was available for 160 patients; 88 (55\%) were germinal center B-cell like and 72 (45\%) were activated B-cell. ${ }^{6}$

The literature from India shows varied incidence as studies from southern India showed that extranodal lymphomas constitute around $22.6 \%$ in contrast to $44 \%$ of occurrence in northern part and $54.7 \%$ in western part, $31.1 \%$ in Northeast India in contrast to our study $41.4 \%$. These variations in frequency in different parts of the same country may be attributed to variation in genetic or ethnic factors, environmental factor as well as the diverse definition criteria. The GIT is the predominant site of extranodal NHL accounting for almost one-third 
Table 2 Comparison of various studies from India relating to primary extranodal lymphomas

\begin{tabular}{|c|c|c|c|c|c|c|c|}
\hline Author and years & Region & $\begin{array}{l}\text { Duration } \\
\text { of study } \\
\text { (y) }\end{array}$ & NHL & pENL (\%) & Age & Site & $\begin{array}{l}\text { Most } \\
\text { common } \\
\text { histological } \\
\text { subtype }\end{array}$ \\
\hline Singh et al, $2003^{4}$ & North India & 3 & 241 & $106(43.9)$ & - & Head and neck & DLBCL \\
\hline Padhi et al, $2012^{5}$ & South India & 5 & 308 & $68(22.07)$ & Mean age 43 y & Brain & DLBCL \\
\hline Aparna et al, $2015^{9}$ & South India & 3 & - & 31 & - & Head and neck & DLBCL \\
\hline Mishra et al, $2015^{2}$ & South India & 3 & 300 & $68(22.6)$ & $\begin{array}{l}\text { Peak incidence 4th } \\
\text { and 5th decade }\end{array}$ & Head and neck & DLBCL \\
\hline Mehta et al, $2016^{8}$ & $\begin{array}{l}\text { North West India } \\
\text { (Rajasthan) }\end{array}$ & 2 & 128 & $70(54.6)$ & $\begin{array}{l}\text { Peak incidence 5th } \\
\text { and 6th decade }\end{array}$ & GIT & DLBCL \\
\hline Pai et al, $2017^{1}$ & South India & 4 & 114 & $41(35.9)$ & Mean age 54.2 y & GIT & DLBCL \\
\hline Lopa et al, $2018^{3}$ & North East & 4 & 257 & $80(31.1)$ & Mean age 51.9 y & Head and neck & DLBCL \\
\hline Present study 2019 & $\begin{array}{l}\text { North India } \\
\text { (Punjab) }\end{array}$ & 3 & 135 & $56(41.4)$ & Mean age 61.3 y & GIT & DLBCL \\
\hline
\end{tabular}

Abbreviations: DLBCL, diffuse large B cell lymphoma, GIT, gastrointestinal tract, NHL, non-Hodgkin lymphomas; pENL, primary extranodal lymphomas.

of all primary extranodal NHL, but this incidence may vary in different areas. Within the GIT, primary gastric NHL is by far the most common, comprising 50 to $60 \%$ of all GIT-NHL, and therefore, considered the most common site of extranodal lymphoma involvement in Korea and India. Another study from south India also emphasized that 15 to $20 \%$ cases of NHL have GIT as their primary site, of which stomach is predominantly affected. ${ }^{7}$ The present study is different as small intestine was the most common site involved; this may be attributed to high inflow of patients suffering from celiac disease and inflammatory bowel disease at our center that is one of the predisposing factors from intestinal lymphomas. One case of peripheral T-cell non-Hodgkin lymphoma NOS of small intestine had prior history of celiac disease.

Head and neck region including Waldeyers' ring has been reported to be the most common sites of origin (44\%) of pENL study from northern India by Singh et al whereas a study conducted by Padhi et al from southern India showed extranodal lymphomas constituted $22 \%$ and the most common site is the central nervous system; the western India shows incidence of $28 \%$ and GIT is the most common site that is affected. Mishra et $\mathrm{al}^{2}$ from South India showed incidence of $22.6 \%$ with head and neck being the most common site of pENHL. ${ }^{4,5,8,9}$ The present study constitutes $41.4 \%$, and GIT is the most common site involved. The data clearly show high incidence of pENL in North India as compared with South India with higher incidence of head and neck origin in South India as compared with North India (- Table 2). These histomorphological diversities of pENL across India are difficult to explain but can be attributed to ethnic, environmental and genetic factors.

\section{Conclusion}

pNELs are common in North India with wide variation in site of involvement as compared with other parts of the country. The diagnosis of pENL is always difficult in the absence of immunohistochemical studies and clinicoradiological information.

\author{
Financial Support and Sponsorship \\ Nil.
}

\section{Conflicts of Interest}

There are no conflicts of interest.

\section{References}

1 Pai A, Kannan T, Balambika RG, Vasini V. A study of clinical profile of primary extranodal lymphomas in a tertiary care institute in South India. Indian J Med Paediatr Oncol 2017;38(3):251-255

2 Mishra P, Das S, Kar R, Jacob SE, Basu D. Primary extranodal non-Hodgkin lymphoma: a 3-year record-based descriptive study from a tertiary care center in Southern India. Indian J Pathol Microbiol 2015;58(3):296-300

3 Lopa K, Sharma J, Manoj K, et al. Extranodal lymphoma: an experience from a tertiary care centre in North-East India. Asia Pac J Res 2018;2:6-9

4 SinghD,KumarL,GoyalH,etal.Primaryextranodalnon-Hodgkin's lymphoma in Northern India. Proc Am Soc Clin Oncol 2003;22:2457

5 Padhi S, Paul TR, Challa S, et al. Primary extra nodal non Hodgkin lymphoma: a 5 year retrospective analysis. Asian Pac J Cancer Prev 2012;13(10):4889-4895

6 Gogia A, Das CK, Kumar L, et al. Diffuse large B-cell lymphoma: an institutional analysis. South Asian J Cancer 2018;7(3):200-202

7 Suresh B, Asati V, Lakshmaiah KC, et al. Primary gastrointestinal diffuse large B-cell lymphoma: a prospective study from South India. South Asian J Cancer 2019;8(1):57-59

8 Mehta J, Thakrar MP, Meena M, Mittal A, Gupta K. Primary extranodal non-Hodgkin lymphoma: a 2-year retrospective analysis from a tertiary care centre in Rajasthan. Int J Med Res Prof 2016;2:76-80

9 Aparna C, Renuka IV, Rajani M, Sailabala G, Annapurna P. Primary extranodal lymphomas - Spectrum of distribution and morphology with immunophenotyping: a 3-year institutional study. Med J DY Patil Univ 2015;8:138-143. 